Historic, Archive Document

Do not assume content reflects current scientific knowledge, policies, or practices. 
62.64

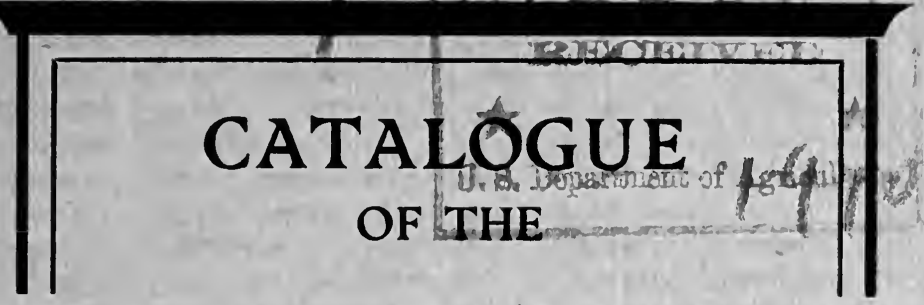
Chicaskia Valley Nurseries

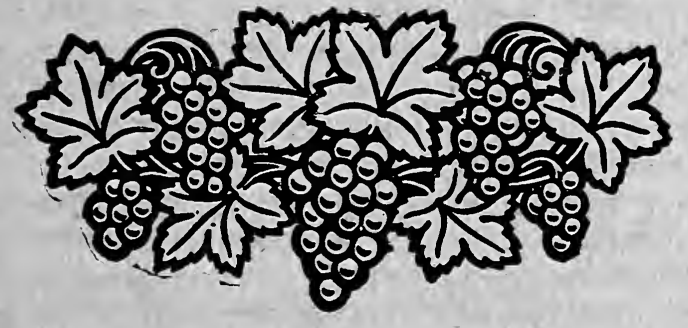

The Leading Mail Order Nurseries of the Southloest

J. W. Tetirick \& Son PROPRIETORS

\section{Blackwell, 0klahoma}




\section{ATTENTION}

By an act of the Oklahoma legislature, 1905, very stringent laws were passed in regard to the handling and shipping of nursery stock. We have complied with the laws, and a copy of the territorial entomologist certificate will accompany each shipment, which is a guarantee to all purchasers that our stock will be clean and healthy.

\section{LOCATION}

Our nurseries are located one mile southeast of the city of Blackwell, being on two lines of the great "Santa Fe" system and one line of the "Frisco," which affords us unexcelled shipping facilities.

For any information not contained herein address

\section{J. W. TETIRICK \& SON, \\ Blackwell, Oklahoma}

Long Distance 'Phone "6" 55. 


\section{TO OUR PATRONS}

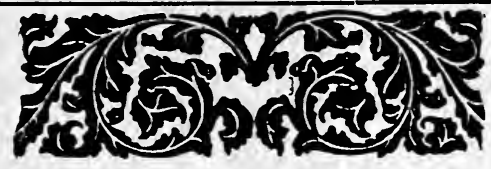

In presenting this plain little catalog, we wish to thank our many patrons for their very liberal patronage, fair dealing and prompt payment, by which we have been enabled to extend our plant of five acres to one of eighty, and also a proportionate increase of facilities for serving our patrons. It is indeed very gratifying to us to know that our efforts in producing the best of stock and our judgment in selecting the best varieties have been so appreciated, and we can now state with increased confidence that with better facilities, broader experience and a determination to keep at the head of our profession, that we are better able than ever before to take care of the wants of our patrons and give them 100 cents on the dollar investment. While it is not our purpose to make this catalog a work of art, nor to deal out a breezy "lingo" of branched plants, unmerited novelty fakes, or whole root "buncombe," yet we are keeping abreast with the times in offering the new fruits of merited value and will continue to do so at a price much below the high salaried agent. It is not our aim to grow cheap trees and plants in order to undersell other firms, but to see how good we can make a tree and then offer it at a fair price.

It is well to look over the bargain counter in purchasing many commodities, but it is a very serious mistake in purchasing nursery stock. Our soil is new and free from aphis and other parasites and fungii that so frequently. infest older nursery soils, and the purchaser can depend on getting stock absolutely free from all such pests.

To all who have not bought of us we kindly ask for a trial order with the assurance that we undertake to give entire satisfacion. We in common with other nurserymen usually have a surplus of one or more items in our stock; one year it may be apple and the next cherry, and so on, and on such lines we are always able to quote lower prices in order to reduce the surplus.

\section{J. W. TETIRICK \& SON: Blackwell, Oklahoma.}




\section{HOW TO PURCHASE FRUIT TREES.}

First, deal directly with the nurseryman, either personally or through the mail. Second, make out it list of the different kinds of fruits you want, stating the num-

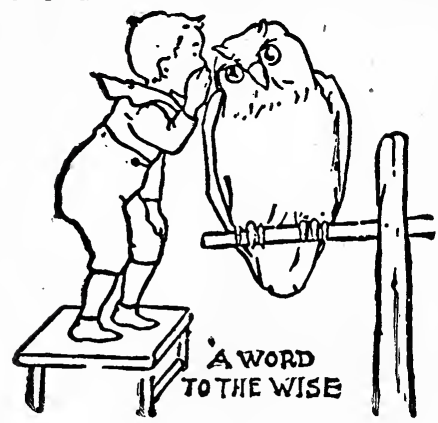
ber wanted and the approximate size and ask for prices. (If by mail get prices on the bill laid down at your nearest railroad station in prime order.) In this way you will know just what your trees will cost, and save from $15 \%$ to $40 \%$ money and get what you buy. In dealing direct with the nurserymen, he has no one to dodge behind in accounting for trees not true to name, poor condition or misrepresentations. By this method of dealing you get the benefit of what intelligence and honor he may have.

Our terms are cash with order or satisfactory reference before shipment, except to prompt paying customers, whose orders will be booked and shipped without the above requirements.

Usually in our latitude and further south fall is the best time for planting, but in case planting cannot be done in the fall we much prefer trees taken up and properly healed in until early spring, when planting may be done early and the trees get the early influence toward spring growth.

We exercise the greatest care in keeping everything true to name and hold ourselves in readiness, upon proper proof, to replace free of charge any trees that do not prove true to name, or refund the purchase price of same, and it is hereby mutually understood that our stock is accented on the above terms.

\section{A FEW DON'TS ABOUT ORCHARD WORK.}

1. Don't prune the small fruit spurs and twigs from your apple and pear trees, for it is this growth that induces early bearing, besides in their removal water sprouts take their place, which is a drawback to the tree and an annoyance to the orchardist.

2. Don't prune your apple trees 'high, for your chances on tall trunks are good for sunscald and borers.

3. Don't allow your standard pear trees to grow up like Lombardy poplars, but keep them headed back annually. This divides lateral growth, induces early bearing and makes your tree less inviting to blight and reduces the chances for damages from high winds.

4. Don't mulch trees after first or second year at farthest. It causes too much surface root growth.

5. Don't plant apple and peach alternately, as the peach is a very rank feeder and grower, and should be planted on the south side of the orchard, making a windbreak for the balance of trees and just as much fruit. 
6. Don't plant fruit trees on wet land, more especially cherry, which should have the best drained land in the orchard.

7. Don't forget to plant plenty of Russian mulberry around your orchard, as their fruit will attract the birds from other fruits which ripen in their season.

8. Don't depend on the 'high-salaried, togged-up, persistent, oily-tongued cuss for good trees; his guarantee is. not worth the pieces of glass that he wears for diamonds.

9. Don't forget when asking for prices on trees to state the different kinds of fruit you want, the number wanted and about the size you would like.

10. Don't select the poorest piece of land you possess for an orchard.

11. Don't forget to use Hi-kem. See page 15.

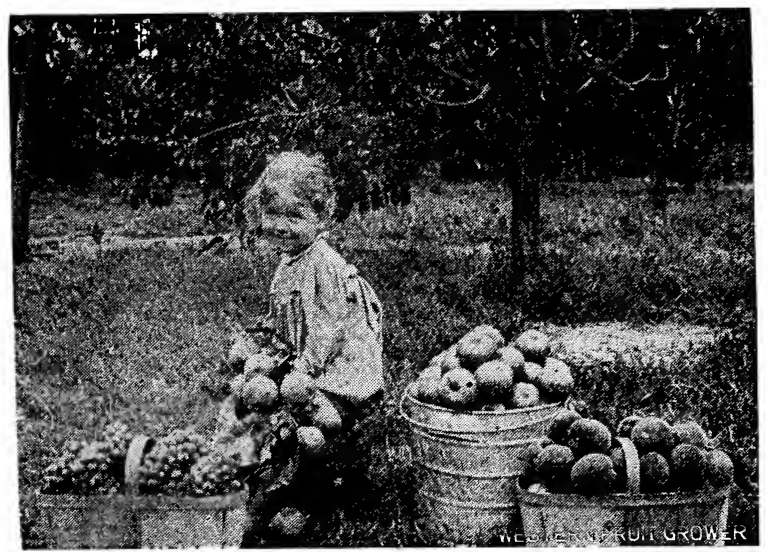

\section{PRACTICAL SUGGESTIONS IN , PLANTING ORCHARDS.}

Select well-drained land, and free it of all litter. Plow deep, harrow well and check it off $16 \times 16$ feet. Begin on south side and plant peaches, then pears, plums, cherries, and then apricots, nectarines, etc.; then finish with apples $16 \times 32$ feet. In this way your trees will all agree and each sort will have plenty of room and cultivation can be dispensed with sooner. Try it. After your peach trees begin to bear they should be looked over annually about July and all borers taken out; and following winter the tops should be cropped back, say about onethird of current year's growth. 'If this method is continued you need plant no more peach trees, as they will live a natural lifetime-try it and be convinced.

(Read No. 9 in Dont's.)

\section{APPLE TREES.}

Our method of propagating and growing them differs very materially from any other that we have seen, and after having compared them with whole-root stock of our own growing and the whole-root trees put out by a number of other firms, we unhesitatingly challenge any of the whole-root growers to show a more thorough and abundant root system than we produce. 
The Apple King of America, Judge Wellhouse of Lawrence, Kas., and Prof. L. H. Bailey, the most noted horticulturist of the age, have both said that the person paying a penny more for the so-called whole-root tree than for a properly grown piece-root tree had thrown their extra money away. This is the verdict of many ot'her men of less note. So the whole-root "buncombe" has gone the way of the "frost-proof apricot," "curculioproof plum" and the "hard-wood peach." Next in order will probably be the "seedless apple." Look out for the agents' quill.

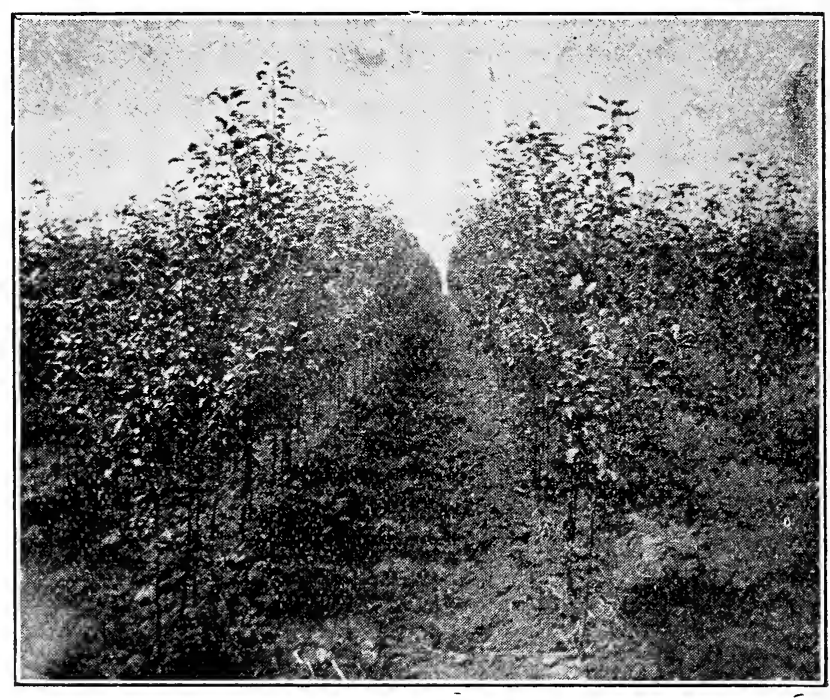

\section{APPLES IN ORDER OF RIPENING.}

EARLY VARIETIES.

Early Colton, very fine. Early Harvest. Yellow Transparent. Red June.

C. E. White.

Red Astrachan.

FALI VARIETIES.
M. Blush.
Lowell.
G. Golden.
Jonathan.

Wolf River, very large.

\section{WINTER VARIETIES.}

Missouri Pippin.

D. W. M. Blush, new and very fine.

N. W. Greening.

M. B. Twig, (Arkansas).

Ben Davis, better than none.

York Imperial, fine.

Winesap.

Gano.

Reagan, (B. Ben Davis, Arkansas), very much like Gano.

Ingram, (Kansas Keeper) good.

Coffelt, (Arkansas Keeper).

Maroon Limber Twig, the best keeper; valuable.

\section{CRABS.}

Whitney, well known.

Soulard, better.

Florence, best of all.

(Use Hi-kem and save your trees and dollars.)

(4) 


\section{DWARF APPLE TREES.}

For the benefit of those persons living in towns where ground room is scarce, we have secured a lot of the French Doucin apple stock and are now propagating them in several varieties. These dwarf trees never exceed five to eight feet in height and are very young and prolific bearers, ofttimes bearing when two feet high, and may be like the Wonder lemon, grown in a candy bucket or other similar vessel. A novelty of merit. Try them.

\section{PEACHES.}

Our varieties are all choice and are named in their order of ripening, covering our season in this latitude from June 10 th to November 1st. (W.) white or green flesh; (Y.) yellow flesh; (S. C.) semi-cling; (C.) cling; (F.) freestone.

Sneed-(W.) (S. C.), best early.

Amsden-(W.) (S. C.), well known.

Triumph-(Y.), free when ripe.

Greensboro-(W.) (F.), one of the best.

Mamie Ross-(W.) (S. C.), very fine.

Early Rivers-(W.), free when ripe; fine.

Carman-Pale (Y.) (F), one of the best.

St. John-(Y.) (F.), very fine.

Mt. Rose-(W.) (F.), hard to beat.

Foster-(Y.) (F.), A No. 1.

Champion-(W.) (F.), one of the very best.

Elberta-(Y.) (F.), well known.

Chinese Cling-(W.), one of the best.

Thurber-(W.) (F.), good.

Wager-(Y.) (F.), fine canner.

O. M. Free-Pale (Y.), one of the best.

Emma-(Y.) (F.), finest canner.

Shinley-(W.) (F.), good.

Heath Cling-(W.), an old favorite.

Salway-(Y.) (F.), best late canner.

Henrietta-(Y.) (C.), best late cling.

We have other sorts being tested.

\section{(Use Hi-kem. See page 15.)}

\section{PEARS.}

We have endeavored to select such varieties that have quality, early bearers and resistance to blight.

Koonce-Best early market.

Alamo-New, very fine.

Early Harvest-Good market, reliable.

Howell-Early and prolific bearer, A. No. 1.

Bartlett-Well known; subject to blight.

Seckle-Small, of finest quality.

Duchess-Large, good, reliable.

Garber-Good grower and bearer.

Kieffer-Well known; good only for canning.

Angou-One of the best; early bearer.

Krull-Winter; good when ripe.

\section{PLUMS.}

Red June-The best early, fine quality, reliable.

Abundance-Good bearer, good quality.

Burbank-The best all around Jap.

Wickson-Large, good, short lived.

Pottawattomie-Small, but most reliable.

Hunt-Very desirable for all purposes.

Lombard-Large and of fine quality.

German Prune-Good; a favorite. 


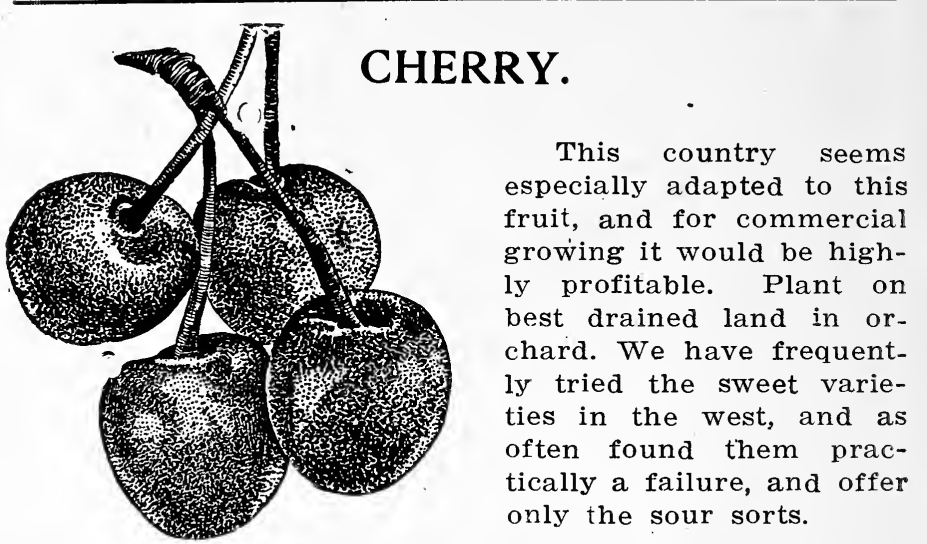

Thirty-Day-The earliest; not fully tested.

Dyehouse-One of the best.

Baldwin-Very fine, large.

Early Richmond-(Early May), universal favorite.

Montmorency Ord.-A No. 1. Try it.

Wragg-Best late sort.

\section{APRICOT.}

Early Golden-One of the best.

Alexis-Russian.

Moore Park-Large and fine; slow grower.

Superb-Said to bloom late.

Royal-One of the best.

\section{QUINCE.}

Champion-Best of all.

Meech-Large.

Orange-Old favorite.

(Use Hi-kem. Read Don't No. 9.)

\section{NECTARINES.}

Boston-Well known.

Pearle-Transparent; fine.

\section{NUTS.}

\section{PAPER SHELT ALMONDS.}

A beautiful tree and hardy in this latitude, and bears well. Try them.

Ne Plus Ultra-Large, fine meats.

I. X. L.-Commercial sort.

\section{PECAN.}

Texas Thin Shell Seedling.

\section{CHESTNUTS.}

American Sweet. Spanish.

\section{JAPAN WALNUT.}

This is the most valuable nut bearing tree that has been introduced for years. Tree is a good grower; beautiful foliage; as easily transplanted as a peach; early and abundant bearer. This nut resembles English.walnut, but a little thicker shell and of the highest butternut flavor. Don't neglect this Jap.

English Walnut-Tender. 


\section{MULBERRY.}

Russian-Valuable for timber and wind-breaks.

Downing's Everbearing-Fine fruit.

Hicks' Everbearing-Good shade and fruit.

\section{PERSIMMONS.}

Finding the Japan sorts not hardy, we offer only the American.

\section{FIGS.}

Figs can be grown in this latitude with a little winter protection, and should be found in every fruit garden.

Brown Smyrna-The hardiest.

\section{RHUBARB.}

Myatt's Linnaeus.

\section{ASPARAGUS.}

Conover's Colossal.

\section{STRAWBERRY.}

All perfect bloomers and the cream of the list.

Excelsior-Earliest; sure; good.

Senator Dunlap-One of the best.

Klondike-New; very promising.

Parker Earle-A No. 1.

Gandy-Large; late.

\section{CURRANTS.}

We have tried several of the newer sorts, but the kinds noted below beat them all with us. Plant in moist, shady situation.

Red Dutch-Best red sort.

White Dutch-Best white; very sweet.

Crandall-Black; for tarts and jellies.

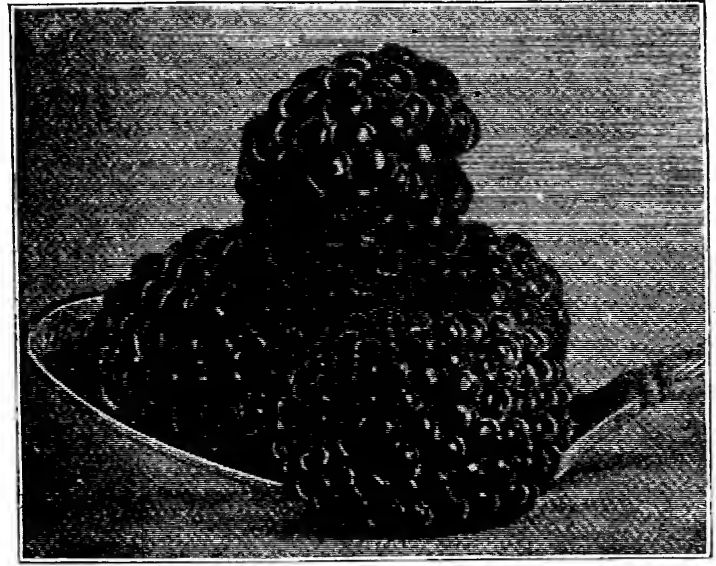

BLACKBERRY.

Early Harvest-A favorite; reliable.

Erie-Larger, later, sweeter, better.

Ildnrado-Finest quality.

Mersereau-Said to be A No. 1.

Lucretia Dewberry-Best trailing berry. 


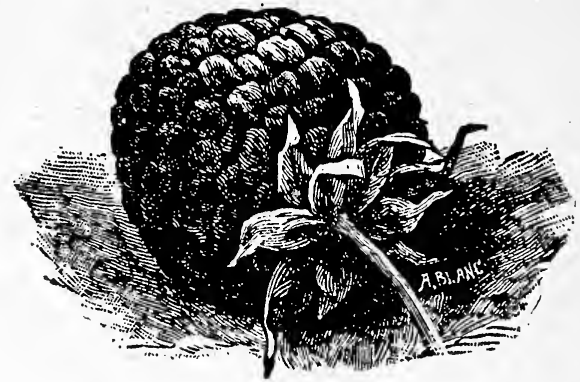

\section{RASPBERRY.}

Miller's Red-The favorite red sort. liansas-Black; A No. 1.

Gregg-Black; large and fine.

\section{GOOSEBERRY.}

Houghton-Most reliable.

\section{JUNEBERRY.}

A sure and reliable fruit. Similar to the Serviceberry. The longer you keep it the more fruit you will have and the better you will like it. Valuable. Try it.

\section{BUFFALO BERRY.}

Native of Dakota. Beautiful shrub, with silvery foliage and tart fruit.

\section{GRAPES.}

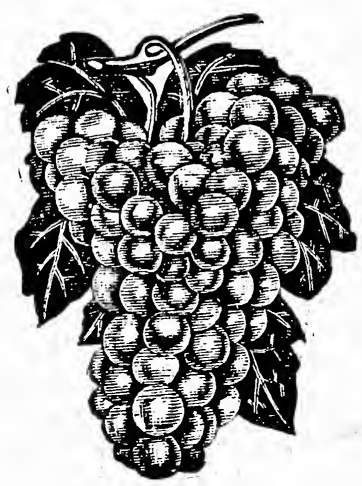

One of the oldest and best of fruits. Easily grown and an "early and abundanit bearer. We grow a few of the very best sorts, covering the whole season of ripening.

Moore's Early-Black; best early market.

Brighton-Red; finest quality.

Moore's Diamond - White; good.

Delavare-Red; small, but of best quality.

Campbell's . Early - Black; good every way.

Niagara-White; old reliable.

Concord-Black; universal favorite.

Catawba-Red; fine for wine.

Woodruff Red-Large and fine quality. Try it.

Goethe-Bronze pink; finest quality. 


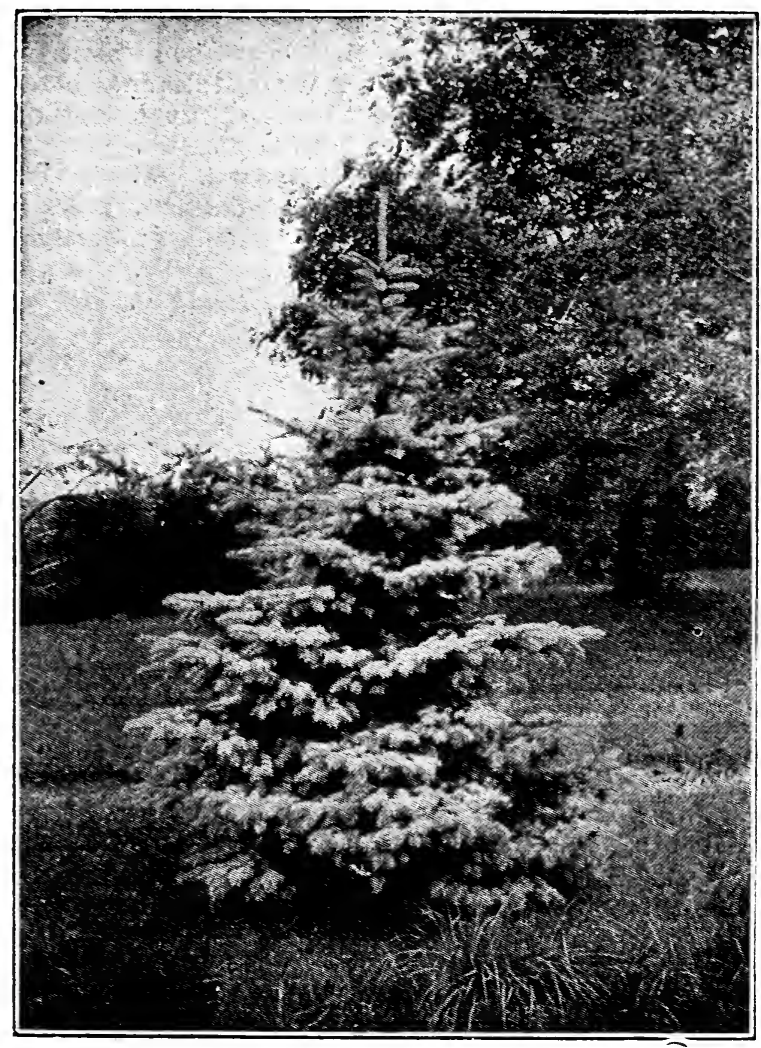

\section{SHADE AND LAWN TREES.}

All having been one or more times transplanted, are worth double the price of seed-bed trees. Sorts marked with a * can be supplied in various sizes from 3 to 15 feet.

*Ash, Green-Stocky grower.

*Ash, White-Well kncwn; good tree.

Birch, White-Beautiful "Lady of the woods."

Birch, Red Canoe-Fine for lawn specimens.

* Catalpa Speciosa-Good for all purposes; succeeds best on bottom land.

* Catalpa Bungeii Cmbrella-The finest ornamental lawn tree yet introduced. Our stock of this tree is unexcelled. Perfectly hardv. Try it.

*EIm, American White-Finest shade for private or public parks.

*Elm, Red-More upright grower.

*Hackberry-Fine for street or avenue.

Horse Chestnut-Fine for lawn.

*Linden, American-Very fine for shade or lawn.

*Locust, Black-Grows where others fail.

Locust, Honey-Pretty foliage.

*Maple, Silver-Universal favorite.

Maple, Sugar-A better tree, of slower growth.

Maple, Norway-Dense head; fine.

Maple, Sycamore-Handsome; broad leaved.

Maple, Scarlet-Very fine for lawn.

Maple, Wier's Cut-Leaf-Very fine lawn tree.

Magnolia- "Sweet Bay" of the South; tender.

*Mulberry, Russian-Well known.

Mulberry, English-Fine fruit and shade.

Mulberry, Downing's-Fine fruit and shade. 
SHADE AND LAWN TREES-Continued.

Mulberry, Weeping-Very'fine lawn ornament.

Oak, Scarlet-Very fine for lawn specimen.

*Poplar, Carolina-One of the best for street or avenue; very rapid grower and rich foliage.

Poplar, Balm of Gilead-Well known.

Poplar, Silver-Good for single specimen.

*Sycamore-A No. 1 for street or shade; easily transplanted; very rapid and symmetrical growth.

*Tulin Tree-Very fine for lawn or shade.

*Willow, American-Ranid growth.

*Willow, Golden-Well known.

Willow, Osier-For ties and basket making.

Walnut, Japan-Valuable shade timber; fruit. Try it.

Varnish Tree-China; rare and beautiful for lawn.

Bechtle Double Crab-One of the finest lawn. Try it.

Pissardii-Fine; purplish red foliage.

Rose Tree-China; very fine for lawn; hardy.

Tamarix Africana-Fine for lawn when full grown.

Tamarix Japonica-Fine plume; blooms June.

Russian Olive-Highest ornamental lawn; hardy. Try it..

\section{FOREST TREE SEEDLINGS.}

Forest tree seedlings from 10 inches to 36 inches of the sorts noted below always in stock:

Catalpa Speciosa. Mulberry, Russian, Maple, Soft. Elm, White. Locust, Black.

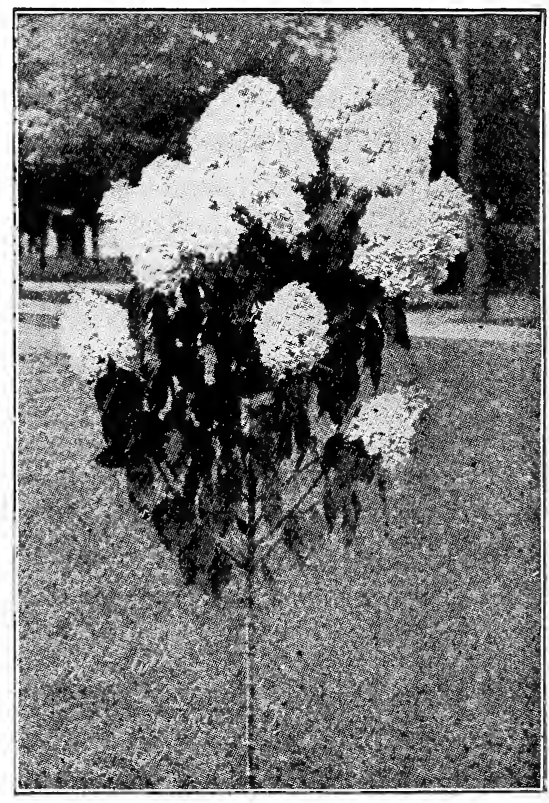

\section{SHRUBS.}

All hardy and mostly of blooming age, and should not be compared with the small plants usually sent out.

Almond, Double Flowering-Early bloomer.

Acacia, Moss Locust-Fine flowering shrub.

Althea-Variegated foliage and flowers.

Althea-Double lilac; very pretty.

Althea-Double red.

Althea-Double white.

Althea-Single white.

Berberley-Purple; very showy. 
SHRUBS - Continued.

Calycanthus-Old fashioned sweet shrub.

Deutzia Crenata-Double, white.

Deutzia Rochester-Tinged pink.

Fringe White Chionanthus.

Fringe Purple (Smoke Tree)-Fine for effect.

Japonica, Scarlet-Blooms in March; fine.

Japonica, White-Blooms in March; fine.

Japan Oleaster-New; fine silver foliage.

Hydrangea Pan. Gran.-Finest lawn shrub extant.

Hydrangea Pan. Gran.-Tree form, 4 to 5 feet.

Lilac, Purple-Blooms first year.

Lilac, White-Blooms first year.

Lilac, Common Purple-Blooms when 6 to 8 years old.

Lilac, Common White-Blooms when 6 to 8 years old.

Lilac, Belle de Nancy-Budded; satiny rose; double.

Lilac, Ludwig Spaeth-Budded; wine red; double.

Lilac, President Grery-Budded; sky blue; double.

Lilac, Mad. Abel Chataney-Budded; pure white; dbl.

The budded lilacs make small trees and their tresses of bloom are very large and fragrant and showy. Try them.

Philadelphus (Mock Orange)-All blooming age, giving a succession of bloom through May and June.

Philadelphus Gordoniorias-Large, white, very sweet.

Philadelphus Coronarius-Smaller flowers.

Philadelphus Speciosus-Very fine and sweet.

Privet California-Fine lawn specimen.

Prunus Triloba-Very fine for lawn; hardy.

Prunus Pissardii-Fine red foliage.

Snowball, Common-Well known.

Snowball, Japan-Much finer; hardy.

Spirea Prunifolia (Bridal Wreath)-Fine shrub.

Spirea Van Houteii-Finest of all Spireas.

Spirea Anthony W.-Blcoms all summer.

Spirea Billiardii-Purple plumes; blooms all summer.

Wigelia Rosea-Very showy when in bloom.

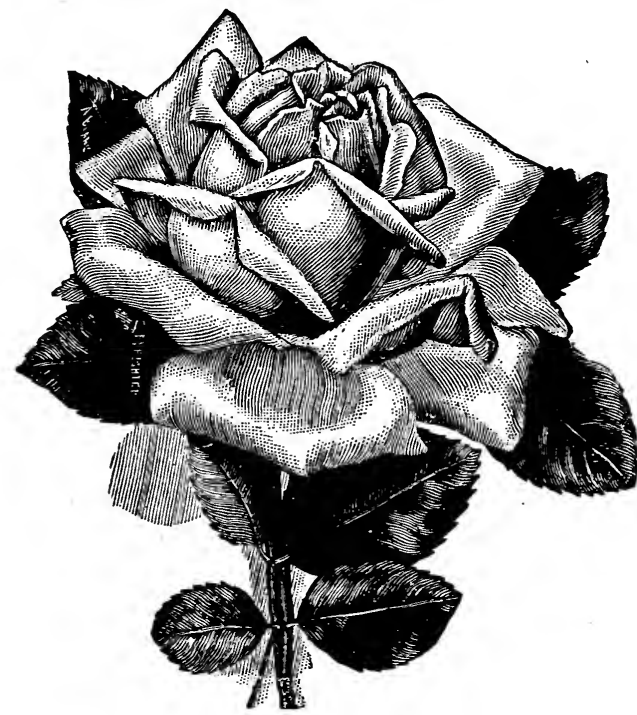

\section{ROSES.}

Our Roses are all propagated and grown in open ground and must not be confounded with weak pot plants. After having tested a great many varieties, we offer such ones that are the most choice for good growth and profuse blooming. 
ROSES-Continued.

Alfred Colomb-H. P., deen cherry red.

American Beauty-H. P., deep red; good for indoor blooming.

Balduin (Helen Gould) Tea-Rosy crimson; one of very best.

Blanche Moreau-Moss; white.

Bridesmaid-Tea; clear pink; fine.

Bride-Tea; white, pink center; fine.

Chas. Lefevre-H. P., glowing crimson.

Clio-H. P., large; waxen white, flesh center; sweet.

Coquette Des Blanches-H. P., white, ball of snow.

Devoniensis-Tea; creamy white, rose center.

Earl of Dufferin-H. P., velvet crimson, dark; very fine.

Etoile De Lyon-Tea; fine; yellow.

Francois Levet-H. P., purplish red; good bloomer.

General Jacqueminot-H. P., well known; A. No. 1.

Gen. Washington-H. P.; A. No. 1; deep crimson.

Gruss and Teplitz-H. tea; velvet crimson; good bloomer; new.

Kiaserine A. V.-Tea; creamy white; very best; very sweet and great bloomer.

La France- $H$. tea; pink, tinged crimson; A No. 1.

Mad. Chas. Wood-H. P.; rosy crimson; good.

Mad. F. Kruger-Tea; coppery yellow and pink; the best grower and bloomer of all; try it.

Mad. Geo. Bevant-H. tea; pure white; constant bloomer; fine for cemetery planting; very hardy. Try it.

Mad. Plantier-Fine for cemetery; white; hardy.

Magna Charta-H. P.; dark pink; one of the best.

Maman Cochet-Tea; pink; one of the best.

Maman Cochet-Tea; white; a beauty; try it.

Marechal Neil-Cli. tea; rich yellow; tender.

Mag. Dickson-H. P.; waxen white; one of the best.

Marshall P. Wilder-H. P.; crimson; A No. 1.

Meteor-H. T.; velvet crimson; A No. 1.

Papa Gontier-Tea; glowing crimson; A No. 1.

Paul Neyron-H. P.; dark pink; largest and best bloomer of its class; best grower. Try it.

Prince Camille de Rohan-H. P.; dark velvet crimson; A No. 1.

Souv. De Wooten-H. T.; dark magenta red; good bloomer.

Ulrich Brunner-H. P.; dark crimson; large; A No. 1.

Vick's Caprice-H. P.; striped white and pink; A No. 1.

Viscountess Folkstone-H. T.; flesh satiny gloss; a beauty.

Winnie Davis-H. T.; apricot pink; a sure beauty.

$\mathrm{O}^{\dagger}$ hher sorts will be offered as tested.

\section{HARDY CLIMBING-COMMON.}

Baltimore Belle-Pale blush; blooms in clusters.

Seven Sisters-White to crimson; blooms in clusters.

Prairie Queen-Rose color; one of the finest.

Gem of Prairie-Red; good.

\section{RAMBLERS-ALL HARDY.}

Crimson Rambler-One of the best.

Yellow Rambler-Fine.

Pinls Rambler-Fine.

White Rambler-Fine.

Fmpress of China-Pink; everblooming when well established. 
ROSES-Continued.

Dawson-Pink; one of the best.

Dorothy Perkins-Shell pink; new; very fine. Try it.

Wichuriana (Memorial Jap) - Good for cemetery plant. ing; white.

\section{EVER-BLOOMING CLIMBERS-HYBRID TEA.}

Marechal Neil-Rich yellow; tender.

Perles Des Jardins-Cream to yellow; tender; best of its class.

Meteor-Dark crimson; a beauty; hardy.

Mrs. Robt. Peary - White; the best of all; hardy.

Wm. Allen Richardson-Yellow; tender.

Other sorts in test.

\section{VINES AND CREEPERS.}

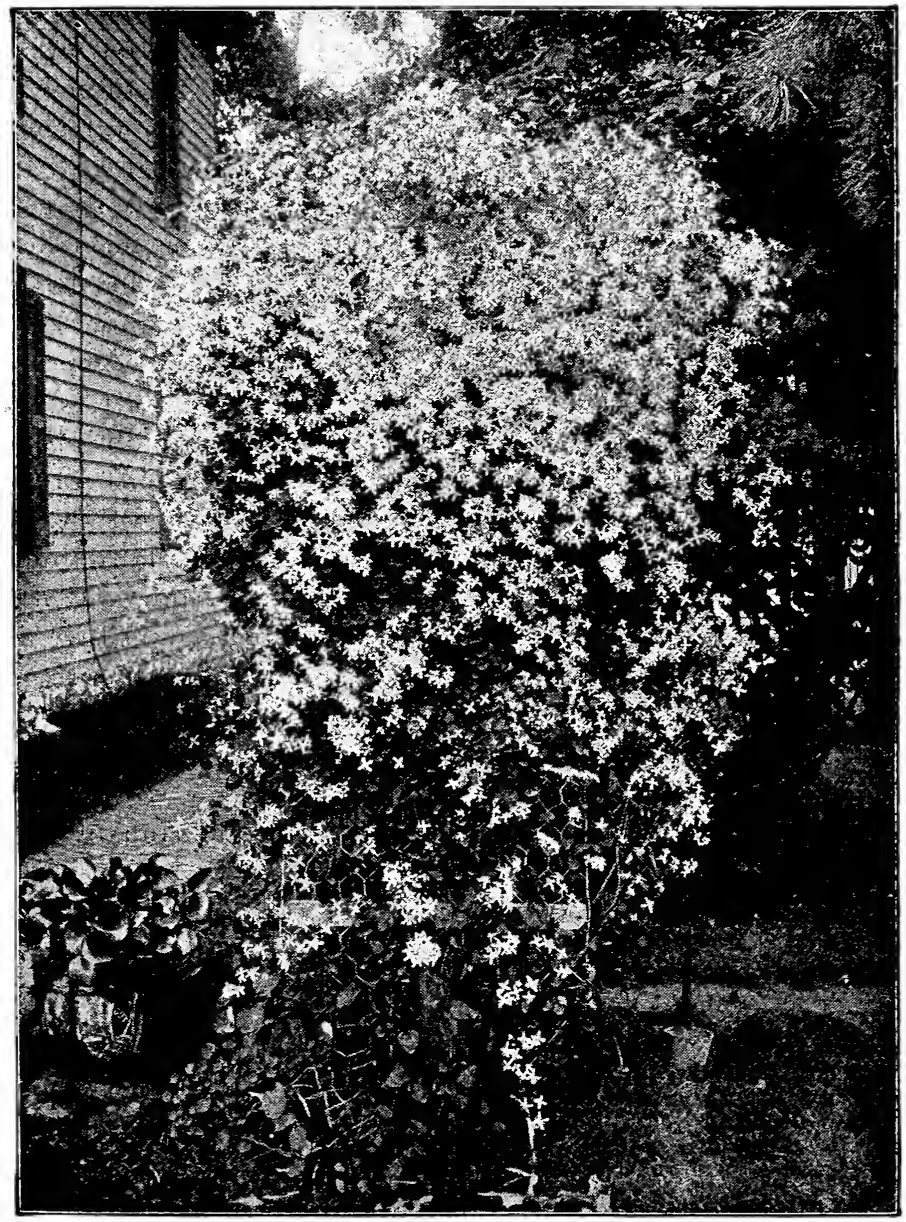

English Ivy-Universal favorite.

Virginia Creeper-Fine.

Trumpet Creener-Old favorite.

Clematis Jackmanii-Purple; fine.

Clematis, Pan. Grand-White; fragrant; very showy.

Bitter Sweet-Red berries; very fine.

Honeysuc:-le-Hall's Japan; everygreen; very fragrant; white and yellow; No. 1. 
Honeysuckle Hecktrodii-Scarlet orange throat; very fine. Try it.

Honeysuckle, Golden Netted-White and yellow variegated.

Yellow Trumpet.

Scarlet Trumpet.

Wistaria-Blue; rapid grower.

Wistaria-White; rapid grower.

Cinnamon Vine-Rapid grower.

Maderia Vine-Ranid grower.

\section{BULBS.}

Paeonies-A few prize sorts; all colors; fragrant .

Cannas, French Dwarf-Assortment.

Tiger Lilies-Single and double.

Gladioli-Assortment.

Tuberoses-Chinese dwarf.

Dahlias-Assortment.

Maderia-Climber.

Golden Glow. Tansy. Spearmint.

\section{EVERGREENS.}

All having been two or three times transplanted and growing on our grounds, can ship them with ball of earth, which practically insures their growth.

Arborvitae Am.-Well known.

Arborvitea Am.-Pyramidal; fine form; easy to transplant.

Arborvitea, Chinese-Pyramidal; fine form; easy to transplant.

Arborvitea, Chinese-Very handsome; easy grower.

Juniper, Irish-Finest for lawn; easy to grow.

Juniper, Prostrate-Spreading; easy to grow.

Pine, Austrian-Good color; a favorite pine.

Pine, Scotch-Easy grower.

Pine, White-Easy and rapid grower; very handsome. Spruce, Norway-One of the best ; easy grower.

Snruce, White-Very fine.

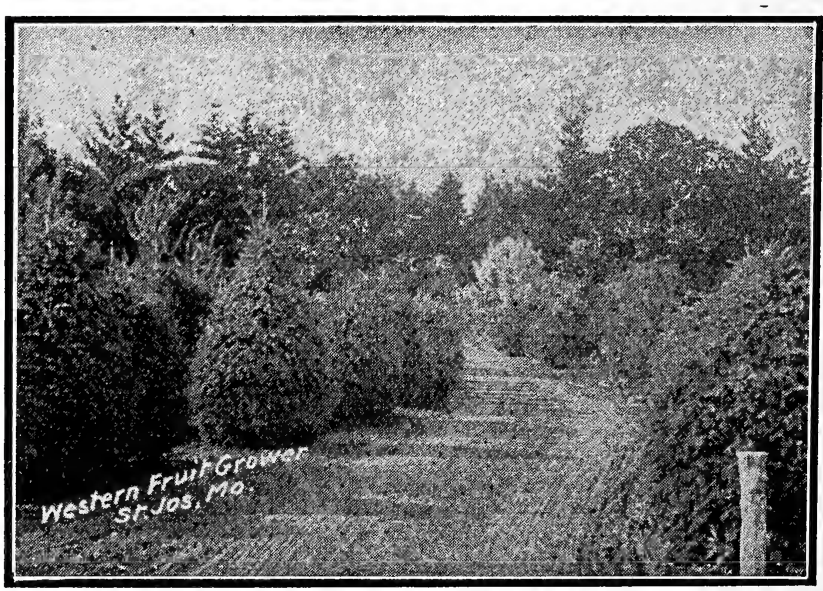

Spruce, Black-Very fine and showy.

Spruce, Kosterina-The most beautiful of all.

Spruce, Douglass-Fine; soft foliage.

Silver Cedar-Fine; hardy; rapid grower.

Rosedale Hybrid-New; very beautiful. Try it. 


\section{EVERGREENS-Continued.}

Tree Box-Very pret‘y little tree.

Mahonia Aquafolia-Holly like foliage; fine and hardy.

Xmas Trees-From 3 to 10 feet.

Evergreen boughs for festooning.

\section{HEDGE PLANTS.}

Osage Orange-Well known.

California Privet-Hardy; best ornamental hedging.

English Privet-Good grower, but blights in scme 1ocalities.

Japonica.

American Arborvitae.

Tamarix.

Berbery.

\section{MISCELLANEOUS, SEEDS, TOOLS.}

Oklahoma Cantaloupes-Originated with us. A cross of Rocky Ford and Hackensack. The best cantaloupe extant. Try it.

Chima-Originated with us, and a cross of Chinese winter and Oklahoma; very fine quality, keeper and shipper, and will lead all of its class.

Corn-Miller's Delight, surest cropper, largest yielder and highest seller in the market.

Hi-kem-Our preparation for preserving trees from rabbits, sunscalds and borers, etc. Good for barked or wounded trees; the thing to apply when pruning. We guarantee it. Directions with each package. Try it and save vour trees and dollars.

Knives for pruning-the best made-Joseph Rodgers \& Sons. Your dealer will not handle them, but we will. A luxury of a knife, and one you can tie to.

Levin's Pruning Shears-The best we haye ever used.

Planet Jr. Garden Tools.

Books on Horticulture.

Sprayers.

Grafting Wax. 



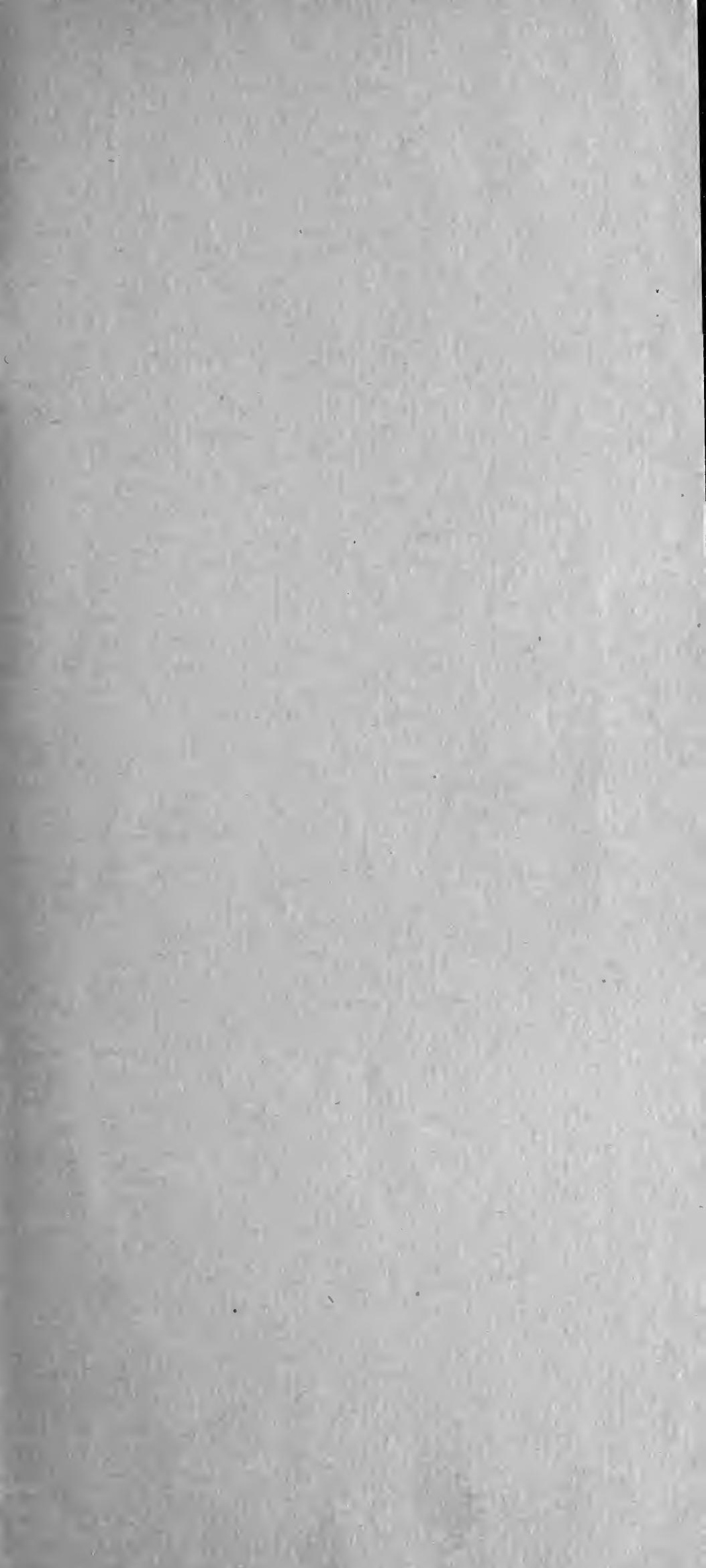




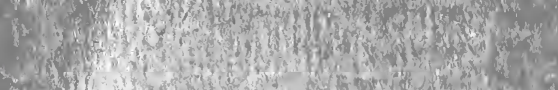

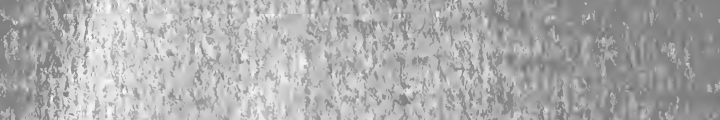

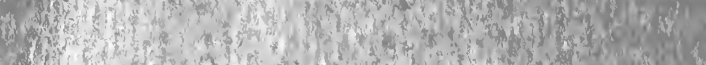

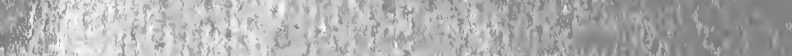

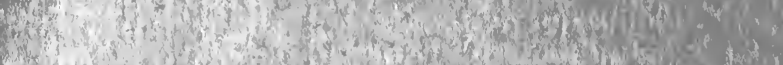

W.

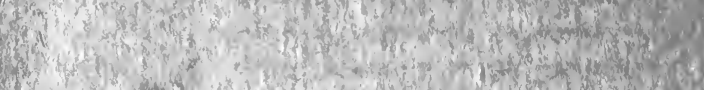

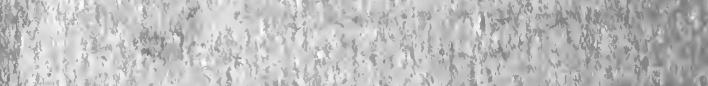

S.

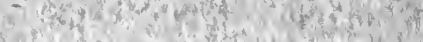

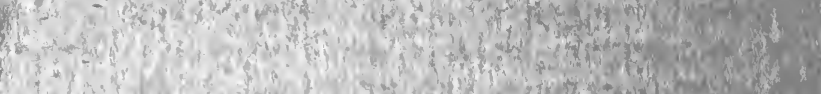

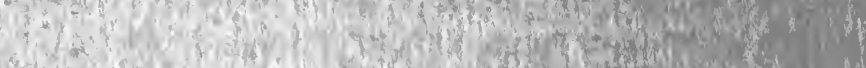
(3)

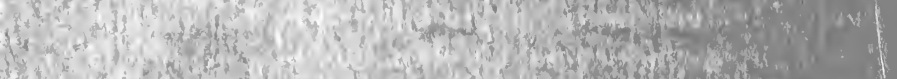

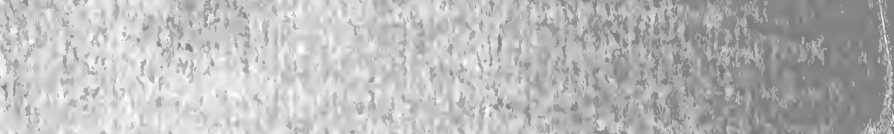

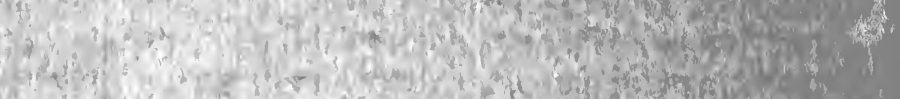

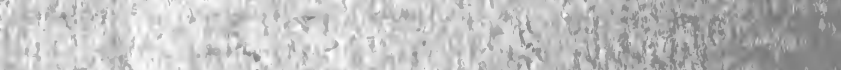

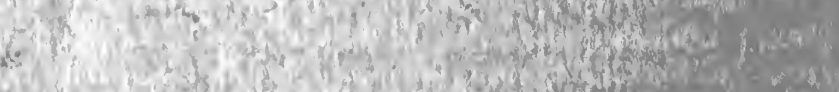

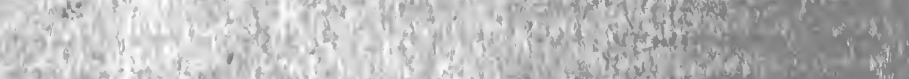

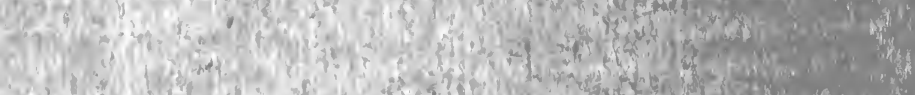

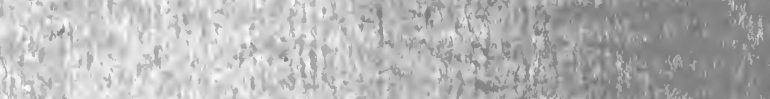

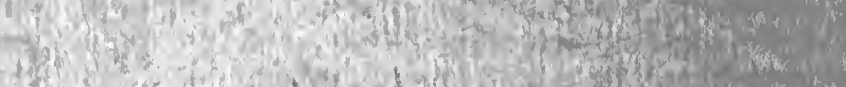

$$
\text { efs }
$$

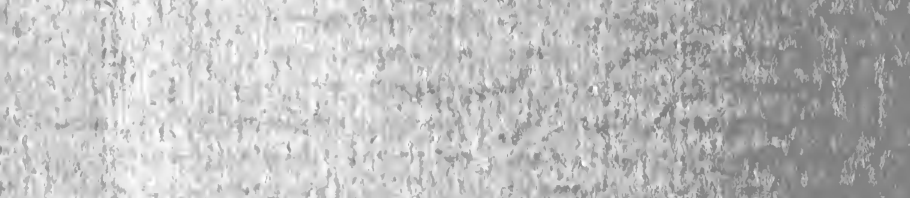

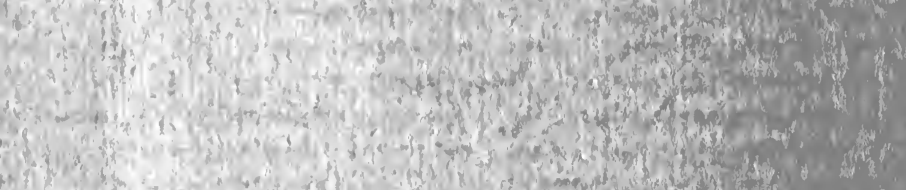

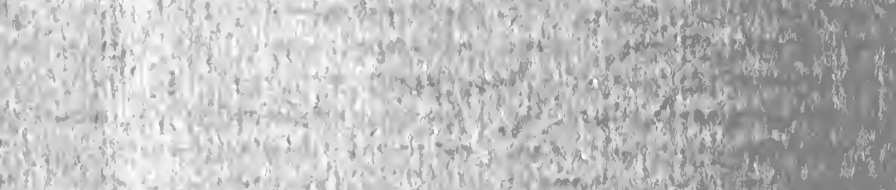

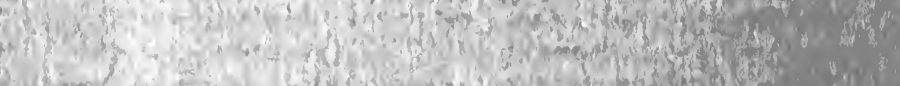

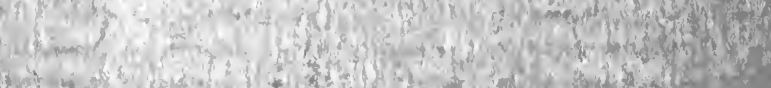
6y

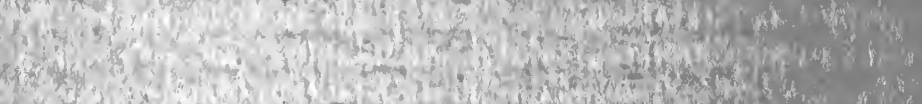

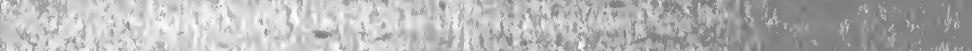
(3)

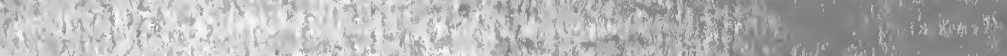

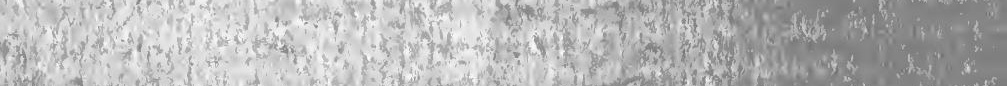

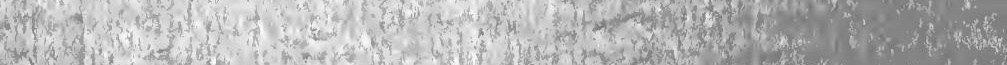

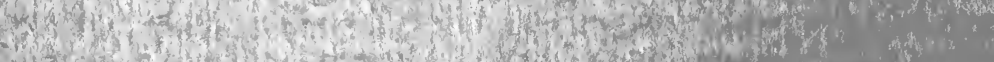

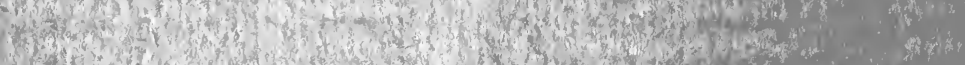
W. Q

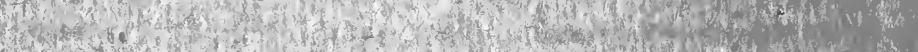

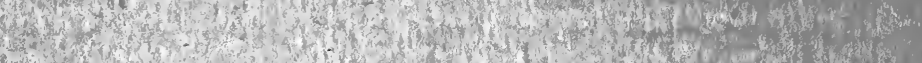

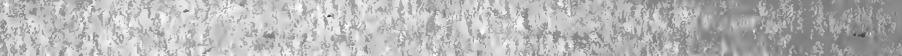

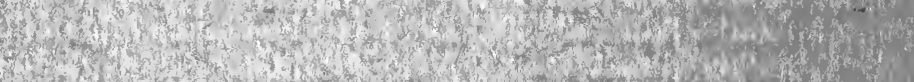

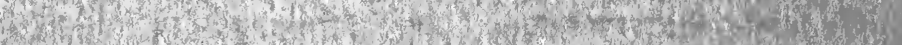

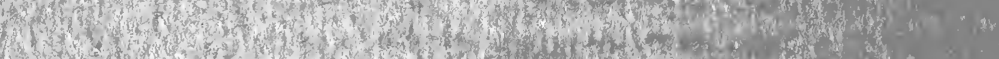

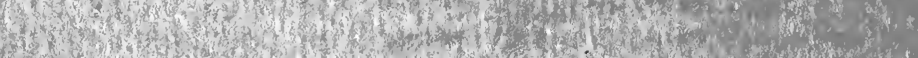
S.

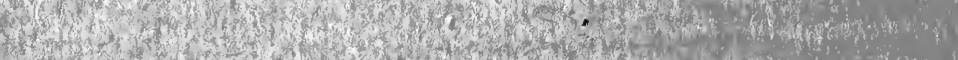

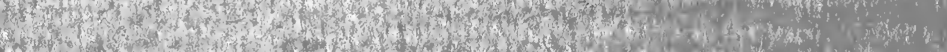
Qf.

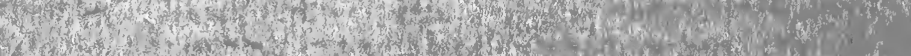

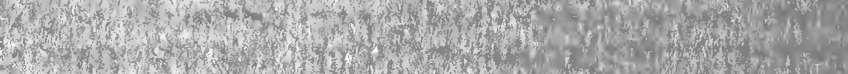

